\title{
Pengaruh Kepribadian Guru Pak Menurut 1 Timotius 4:12 Dalam Pembentukan Karakter Peserta Didik Di SDTK Real Tanjungpinang
}

\author{
Rosnita Temba Kagu ${ }^{1 *}$, Selvyen Sophia ${ }^{2}$, Mangaranap butar-butar ${ }^{3}$ Agiana Her \\ Visnhu Ditakristi ${ }^{4}$, Manahan Uji Simanjuntak ${ }^{5}$ \\ $1,3,4,5$ Prodi PAK, STT Real Batam \\ ${ }^{2}$ Prodi Teologi, STT Real Batam \\ rosnitatembakagu@gmail.com
}

\begin{abstract}
The writing of this paper is based on the problem of several students related to the excuse of not doing the PAK subject assignments at the Tanjungpinang Real Christian Theology Elementary School. The author himself tries to observe this often causes other students to tend to imitate this irresponsible act. This study aims to map students' character problems and review the personality competencies of PAK teachers based on 1 Timothy 4:12. This study uses descriptive qualitative research methods. The results showed that the honest personality of the PAK teacher had a positive impact on the character of the students.

Keywords: Influence, Teacher's Personality, Character Building, Students
\end{abstract}

\begin{abstract}
Abstrak
Penulisan paper ini bertitik tolak dari masalah beberapa peserta didik terkait dalih jika tidak mengerjakan tugas mata pelajaran PAK di Sekolah Dasar Teologi Kristen Real Tanjungpinang. Penulis sendiri mencoba mengamati hal ini kerap menyebabkan peserta didik lain cenderung meniru tindakan yang tidak bertanggungjawab ini. Penelitian ini bertujuan untuk memetakan permasalahan karakter peserta didik dan mengulas kompetensi kepribadian guru PAK berdasarkan 1 Timotius 4:12. Penelitian ini menggunakan metode penelitian kualitatif deskriptif. Hasil penelitian menunjukkan kepribadian guru PAK yang jujur berdampak positif bagi karakter peserta didik.

Kata kunci: Pengaruh, Kepribadian Guru Pak, Pembentukan Karakter, Peserta Didik
\end{abstract}




\section{PENDAHULUAN}

Setiap Seiring berkembangnya Ilmu pengetahuan dari generasi kegenerasi khususnya perkembangan Teknologi yang sangat pesat dan banyak mempengaruhi karakter,seperti pendapat ahli : Wall Hollindale, Bakhtin dan Stephens : "The faster high technology impacted children characteristic (kemajuan pesat tehnologi tinggi mempengaruhi karakter anak-anak)" "akhlak dan budi pekerti para generasi Bangsa Indonesia secara umum dan bagi generasi Umat Kristen secara khusus yang membuat perubahan zaman semakin tidak terkendali dampak negatifnya terhadap generasi muda khususnya peserta didik. Noh Ibrahim Boiliu dkk menjelaskan kerangka pemikiran atau pandangan dunia tentang pendidikan karakter menurut Yesus didasarkan pada perubahan batin dalam diri seseorang. Ini adalah motif atau dasar dari setiap manusia untuk melakukan segala sesuatu atau tindakan serta karakter. ${ }^{2}$

Dari dunia pendidikan lebih jauh dituding sebagai kesalahan guru. Benarkah ada unsur " salah " pada guru? Mungkin " ya" dan mungkin " tidak" tergantung dari sudut mana bahkan ada beberapa pihak yang menuding bahwa krisis nasional sekarang ini bersumber dari cara memandang dan menilainya. Guru memegang peran utama dalam pembangunan pendidikan, khususnya yang diselenggarakan di sekolah secara formal. Guru juga sangat menentukan keberhasilan peserta didik, terutama dalam kaitannya dengan proses belajar mengajar. Guru merupakan komponen yang paling berpengaruh terhadap terciptanya proses dan hasil pendidikan yang berkualitas. Namun yang terjadi saat ini dimana tidak sedikit guru tidak lagi menjadi teladan bagi peserta didik dalam perkataan maupun perbuatan.

Ada beberapa latar belakang yang menjadikan guru kurang berkualitas antara lain adanya guru pendidikan agama kristen yang masih belum hidup sesuai dengan Firman Tuhan, yaitu bagaimana hubungannya dengan Tuhan setiap hari lewat doa, pembacaan Firman, persekutuan untuk membekali kehidupan rohani guru, masih adanya juga guru ketika di lingkungan sekolah tidak menjadi teladan di depan peserta didik yaitu merokok di lingkungan sekolah, menggunakan Handphone saat proses belajar mengajar, dan ada juga guru yang terlambat masuk kelas sesuai dengan waktu yang sudah di tentukan. Saat mengajar adanya Guru

${ }^{1}$ Stephens Wall Hollindale, Bakhtin, Childrend's Literature Pat Pinsent (Palgrave Mac Millan, United State: Copyright Licency Agency, 2016).

${ }^{2}$ Noh Ibrahim Boiliu et al., "Mengajarkan Pendidikan Karakter Melalui Matius 5:6-12," Kurios (Jurnal Teologi \& Pendidikan Agama Kristen) 6, no. 1 (2020): 61-72. 
Pendidikan Agama Kristen kurang mempersiapkan materi yang akan disampaikan kepada peserta didik dan itu sudah mengurangi kualitas seorang guru yang harusnya menjadi teladan.

Oleh Oleh sebab itu, guru perlu memiliki kualifikasi karakter yang baik dalam membentuk peserta didik, memberi motivasi yang baik kepada peserta didik untuk memiliki moral, mendorong peserta didik untuk memiliki intelektual yang tinggi, memberikan gagasan yang luas kepada peserta didik untuk memiliki budi pekerti tentang bagaimana cara beriman dan bertaqwa terhadap Tuhan Yang Maha Esa, memberi pemahaman yang baik tentang nilai-nilai kekristenan.

Sehubungan dengan itu maka dalam penulisan skrispsi ini penulis merumuskan masalah sebagai berikut, Pertama: Bagaimanakah Membentuk Kualitas Karakter Kejujuran Peserta Didik di Sekolah Dasar Teologi Kristen Real Tanjungpinang?, dan Kedua : Bagaimanakah Kompetensi Kepribadian Guru PAK menurut 1 Timotius 4:12 dalam Membentuk Kualitas Karakter Kejujuran Peserta Didik di Sekolah Dasar Teologi Kristen Real Tanjungpinang?

\section{METODE}

Teknik pengumpulan data yang dilakukan penulis yaitu dengan mengumpulkan refrensi buku-buku yang mendukung dalam proses penulisan skripsi ini melalui perpustakaan yang ada sebagai narasumber. Setelah datadata yang diperluhkan berhasil dikumpulkan maka tahapan selanjutnya, penulis menggunakan pengolahan atau analisis data dengan eksegese ayat Alkitab 1 Timotius 4:12. Setelah penulis mengevaluasi dan mengamati serta menganalisa ayat 1 Timotius 4:12 maka penulis temukan Kompetensi Guru PAK untuk meningkatkan karakter Peserta Didik Di Sekolah Dasar Teologi Kristen Real Tanjungpinang. Setelah pengolahan data melalui analisis eksegese selesai dilakukan maka penulis dapat mengetahui apakah hipotesis yang penulis buat sesuai engan hasil penelitian atau tidak sesuai penelitian. Selanjutnya penulis dapat mengambilkesimpulan dari penelitian yang telah penulis lakukan. Kesimpulan yang penulis peroleh dari hasil penelitian dapat mendukung hipotesis yang penulis buat, tetapi kesimpulan yang penulis ambil harus dapat menjawab permasalahan yang melatar belakangi penelitian.

\section{HASIL DAN PEMBAHASAN}

Aplikasi Terhadap Pembentukan Kualitas Karakter Peserta Didik Seorang Guru Harus Menjadi Teladan Dalam Perkataan

Menelaah 1 Timotius dapat membantu peserta didik meningkatkan kesadaran mereka tentang pentingnya mengajarkan ajaran yang sehat dalam 
Gereja. Peserta didik juga dapat memperdalam apresiasi mereka bagi belas kasihan Juruselamat dan bagi peran penting uskup dan pemimpin Gereja lainnya. Karena dalam 1 Timotius dapat di terapkan bagi peserta didik, karena pengajarannya tentang keteladanan dalam mengajar, mendidik dan membimbing peserta didik dan kaum dewasa.

\section{Study Eksegese 1 Timotius 4:12}

Firman-Nya berkata: "Jangan seorangpun menganggap engkau rendah karena engkau muda. Jadilah teladan bagi orang-orang percaya, dalam perkataanmu, dalam tingkah lakumu, dalam kasihmu, dalam kesetiaanmu dan dalam kesucianmu”.

\section{Menganggap Rendah}

Dalam Bahasa Yunani "atafroneitw(kataproneo), dalam bahasa inggrisnya despised artinya dipandang rendah. Kata ini ditulis dalam bentuk subjek orang ketiga tunggal. Paulus memberi tahu Timotius bahwa usianya yang relatif muda bukanlah penghalang dalam hal menjalankan injil dan melayani di Gereja. Pengertian muda dalam bahasa Yunaninya neo, thtoj dalam bahasa inggrisnya Youth/Young artinya muda, kata ini disebut kata benda genetif umum feminim tunggal. Banyak kaum muda telah memiliki pengalaman rohani yang luar biasa. Seperti dalam kitab, yang muda di pakai Tuhan untuk melayani umat: 1 Samuel 17:12-49 (Daud), (Yakub), (Mormon) dan (Joseph Smith). Dari nats ini setiap para guru hendaknya menanamkan dalam hati para didiknya tentang benih-benih kasih amal, kasih murni Kristus. Karena dalam keteladan guru sangat mempengaruhi bagi peserta didik.

Setiap peserta didik tidak akan pernah memandang muda tua nya usia seorang guru. Akan tetapi setiap peserta didik akan melihat karakter seorang guru dalam mengajar. Begitu juga setiap guru, disaat melakukan proses belajar mengajar jangan memandang muda tuanya usia dalam setiap usia. Karena itu tidak akan menjadi penghalang bagi orang-orang dalam menuntut ilmu. Kecerdasan sorang peserta didik bukan dari usia, akan tetapi dari sikap, karakter dan tingkahl aku.

Jadi dari nats 1 Timotius 4:12 ini kita sebagai guru harus belajar untuk tidak menganggap bahwa setiap orang yang kita ajari terlalu rendah dari segi usia. Karena Tuhan juga bisa memakai semua orang untuk melayani umat-Nya dan melayani Tuhan bukan karena usia muda atau tuannya. 


\section{Menjadi Teladan}

Dalam Bahasa Yunani “tupoj” (tupos) artinya bekas, patung, pola, contoh, teladan, dalam bahasa Inggris Behavior, image, statue, form, figure, pattern, mold, perh. content (arche) type, pattern, model, design, technically in the moral life example, pattern. Kata ini ditulis dalam bentuk kata benda jenis kelamin maskulin tunggal. Kata behaviour ini sendiri berbicara mengenai perilaku yang terus menerus dilakukan seseorang dan menjadi kebiasaan. Dari studi kata diatas ditemukan bahwa teladan yang dimaksudkan disini adalah : seseorang atau manusia yang harus menjadi contoh, teladan dan menjadi pola bagi orang lain. Tupos(tupoj) dalam bentuk nominatifnya yang menyebut subjek kalimat adalah tupos yang berarti model dengan demikian seorang guru untuk meningkatkan kualitas mendidiknya, dimulai dengan kepribadiannya yaitu menjadi model/pola serta teladan yang patut ditiru orang lain terutama kepada peserta didik. Jadi Guru khususnya Guru Pak juga harus memiliki karakter menurut pandangan umum sebagai berikut: Religius, Jujur, Toleransi, Disiplin, Kerja Keras, Kreatif, Mandiri, Demokratis, Rasa Ingin Tahu, Semangat Kebangsaan, Cinta Tanah Air, Menghargai Prestasi, Bersahabat/Komunikatif, Cinta Damai, Gemar Membaca, Peduli Lingkungan, Peduli Sosial, Tanggung Jawab, Berpola Hidup Sehat, Cinta Terhadap Ilmu Pengetahuan, Selalu Berfikir Logis, Kristis dan Inovatif. ${ }^{3}$

Paulus mengiginkan Timotius menjadi orang yang memiliki kebiasaan yang baik, terus menerus dilakukan agar Timotius menjadi pribadi

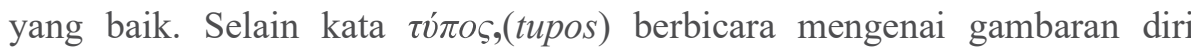
Timotius yang menjadi gambaran Allah dalam kehidupan sekarang. Perilaku yang Paulus inginkan dari Timotius, bahwa Timotius untuk memastikan bahwa ajaran yang sehat diajarkan dan tidak membiarkan kesalahan populer untuk mengalihkan perhatian dari ajaran-ajaran Injil. Dia mengajari Timotius mengenai jabatan uskup dan diaken serta membahas kualifikasi bagi mereka yang melayani dalam jabatan ini. Paulus juga menuturkan kembali rasa syukurnya yang mendalam bagi belas kasihan yang dia terima dari Yesus Kristus ketika dia diinsafkan. Berbicara dengan Integritas yang baik dan ketulusan hati yang besar.

\section{Menjadi Teladan dalam Perkataan}

Dalam Bahasa Yunani $\log w \mid,(\log o s)$ artinya kata, perkataan, sabda; kabar baik, kotbah, pemberitaan, bicara, pembicaraan, laporan, cerita,

${ }^{3}$ Teddy Supryadi \&Anggi Setia Lengkana Tatang Muhtar, Pendidikan Karakter Dalam Pembelajaran Penjas (Bandung: CV. Salam Insan Mulia, 2019). Hal. 1 
peribahasa, pertanyaan, masalah, tuduhan, buku, risalah, catatan keuangan, pertanggungjawaban (sebab dalam kelihatannya pun harus jadi teladan). Dalam bahasa Inggris Speech artinya pembicaraan, kata, perkataan, sabda; kabar baik, kotbah, pemberitaan, bicara, pembicaraan, laporan, cerita, peribahasa, pertanyaan, masalah, tuduhan, buku, risalah, catatan keuangan, pertanggungjawaban, sebab dalam kelihatannya pun harus jadi teladan. Kata benda ini ditulis dengan kata benda umum yaitu kata benda datif (digunakan sebagai objek penderita maskulin tunggal).

Berasal dari kata dasar logoj (logos) yang digunakan sebagai istilah umum untuk perkataan, tetapi juga sering sebagai kata atau berita (Mat. 22:46); bisa juga dipakai sebagai firman atau berita dari Tuhan, (Yoh. 1:1); juga dipakai untuk menyatakan isi dari pemberitaan (Luk. 5:1). Dalam hubungannya dengan konteks ayat ini, Timotius diperintahkan untuk menjadi teladan dalam perkataan, baik yang ia sampaikan secara pribadi kepada beberapa orang maupun yang disampaikan di depan umum.

Perkataan tersebut diatas berhubungan erat dengan pengajaran tentang doktrin.(en logoi) dalam bentuk tunggal maka yang dimaksudkan adalah seluruh perkataan Timotius harus menjadi panutan atau teladan bagi orang lain.Perkataan selalu berhubungan dengan lidah. Lidah adalah bagian tubuh yang sekalipun kecil tetapi sulit untuk dikendalikan dan dikuasai. Firman Tuhan mengatakan bahwa jika seseorang bisa mengendalikan lidahnya maka ia adalah orang yang sempurna dan dapat juga mengendalikan tubuhnya. Yesus mengatakan, masalah lidah juga menyangkut masalah hati, karena 'yang diucapkan mulut meluap dari hati'. Orang yang dapat mengendalikan lidahnya adalah orang-orang yang mempunyai perbendaharaan yang baik dalam hatinya. Menurut Plato "Wise men speak because they have something to say; Fools because they have to say something".yang bahasa indonesianya "orang bijak hanya berbicara jika mereka mempunyai sesuatu yang harus dikatakan;tetapi orang bodoh berbicara karena mereka harus mengatakannya". ${ }^{4}$ Talizaro Tafona'o mengatakan bahwa Kepribadian Guru Kristen Dalam Perspektif 1 Timotius 4:11-16 69 sesuatu. ${ }^{5}$ Sebab itu, setiap orang perlu mengendalikan apa yang mereka hendak katakan dengan menguasai lidahnya, karena adalah lebih baik untuk lambat berkata-kata daripada cepat berkata-kata dan selalu menemui

\footnotetext{
${ }^{4}$ Mamutty Chola Plato, "Pearls of Wisdom," BecomeShakespeare.Com, 2019. Hal. 1

${ }^{5}$ Talizaro Tafona'O, "Kepribadian Guru Kristen Dalam Perspektif 1 Timotius 4:11-16," Evangelikal 3, no. 1 (2019): 66, https://journal.sttsimpson.ac.id/index.php/EJTI/article/view/115.
} 
masalah pada akhirnya. Dalam Yakobus 3:2 dikatakan, "Sebab kita semua bersalah dalam banyak hal; barangsiapa tidak bersalah dalam perkataannya, ia adalah sempurna, yang dapat juga mengendalikan seluruh tubuhnya." Itu berarti, menguasai lidah adalah hal yang sangat penting karena berhubungan dengan perkataan.

Keteladanan dalam perkataan berarti penguasaan diri atas lidah dan ucapan yang dikeluarkan. Lima hal pokok berkaitan dengan hal itu seperti uraian dari 1 Timotius 4:12 yakni:

a. Keteladanan dalam menyimpan rahasia. Setiap orang harus berusaha untuk dapat menyimpan rahasia orang yang telah dipercayakan kepadanya. Jika orang tidak mampu menyimpan rahasia maka ia akan dijauhi oleh temantemannya. Seperti dikatakan, "Siapa mengumpat, membuka rahasia, sebab itu janganlah engkau bergaul dengan orang yang bocor mulut (Ams. 20: 19).

b. Keteladanan dalam penguasaan lidah terhadap perkataan negatif. Perkataan yang negatif dapat memengaruhi orang-orang di sekelilingnya. Perkataan yang negatif dari sepuluh orang mata-mata yang diutus untuk mengintai tanah Kanaan mengecilkan hati semua orang Israel dan menyebabkan mereka berkeluh kesah dan mengeraskan hati terhadap janji-janji Allah. (U1. 1:28).

c. Keteladanan untuk tidak mengucapkan kata-kata yang menyakitkan/cemooh. Mengolok-olok seseorang adalah perbuatan yang sangat menyakitkan hati, khususnya ketika seseorang mengolok-olok atau mempermainkan nama seseorang, penguasaan lidah atas cerita-cerita dan humor jorok, dapat membentuk gambaran yang kotor juga di dalam pikiran orang, baik yang mengatakan, maupun yang mendengarkan. (Kol. 3:8), mengejek keluarganya atau masalah fisiknya. Ketika seseorang melakukan sesuatu yang melukai hati, maka sebaiknya seseorang tidak perlu membalas dengan ucapan-ucapan yang juga menyakitkan. Tetapi sebaliknya harus belajar dari Tuhan Yesus yang setia mengendalikan bibirNya untuk tidak membalas, memaki-maki, mengancam dan menyumpahi orang yang telah menyakiti-Nya (Yes. 53:7; I Pet. 2:22-23).

d. Keteladanan untuk tidak bicara tentang dusta dan tipu daya. Allah tidak suka dengan dusta atau tipu daya, sebab itu perintah untuk jangan mengucapkan saksi dusta termasuk di dalam kesepuluh firman (Kel. 20:16), tidak terbawa arus untuk memfitnah atau menggosipkan, Jika yang ditabur adalah fitnah maka akibatnya akan timbul kepahitan dan buah-buah 
yang buruk. Istri Potifar memfitnah Yusuf yang mengakibatkan Potifar yang mendengarnya menjadi marah. (Kej. 39:17-19). ${ }^{6}$

e. Keteladanan untuk tidak memuji atau merayu berlebihan. Rayuan adalah salah satu bentuk dari perangkat Iblis. Manusia jatuh ke dalam dosa karena rayuan Iblis. Demikian pula, seseorang dapat jatuh karena kata-kata rayuan orang lain. Pujian yang tulus atau kata-kata yang membesarkan hati atau memberi semangat memang diperlukan dan sangat besar artinya, tetapi pujian yang berlebihan yang tidak sesuai dengan kenyataan merupakan suatu kebohongan yang berbahaya. (Maz. 5:10).

Perkataan memegang peranan yang sangat penting dalam kehidupan setiap orang khususnya dalam pergaulan dengan orang lain. Dalam sebuah keluarga, perkataan yang digunakan sangat berpengaruh pada perkembangan peserta didik. Perkataan yang baik dapat memberikan kesehatan rohani, mental dan jasmani. Allah mengajarkan agar setiap orang tidak menggunakan ucapan yang negatif, khususnya orang tua kepada anakanaknya karena perkataan yang negatif seperti goblok, bodoh, canggung, malas, pemalu, buruk, dan lain-lain dapat membuat anak menjadi sosok yang tidak percaya.

Segala ucapan negatif yang diterima anak akan melekat dalam hatinya, dan mereka akan cenderung menjadi sosok dan bertindakseperti julukan yang diberikan kepadanya. Daripada orang tua memberikan julukan negatif kepada anak-anaknya, akan lebih baik jika orang tua atau guru memberikan pujian kepada anak-anaknya. Memuji anak-anak merupakan tindakan dan sikap yang positif. Dengan memberikan pujian kepada anak, mereka akan bertumbuh menjadi anak yang dapat bersyukur kepada Tuhan dan menghargai orang lain. Dapat dipahami bahwa setiap orang, baik yang tua maupun yang mudah harus berusaha untuk dapat menguasai lidahnya sehingga setiap perkataan yang keluar dari mulutnya bukanlah perkataan yang sia-sia dan perkataan yang kotor, tetapi perkataan yang dapat membangun orang lain. Paulus mengatakan, "Janganlah ada perkataan kotor keluar dari mulutmu, tetapi pakailah perkataan yang baik untuk membangun, dimana perlu, supaya mereka yang mendengarnya beroleh kasih karunia".

Kata-kata kotor yang membinasakan dikatakan keluar dari mulut sebetulnya berasal dari hati. Daripada menggunakan kata-kata kotor yang keluar dari hati, disarankan untuk menggunakan kata-kata yang bersifat baik dengan istilah yang digunakan Paulus "logos agathos". Sebab perkataan yang baik akan mendatangkan kebaikan atau membangun bagi yang

\footnotetext{
${ }^{6}$ David Susilo Pranoto, "Manna Reflesia" (Sekolah Tinggi Teologi Arastamar
} Bengkulu, 2017). 
mendengarnya. Membangun bagi mereka yang mendengarnya memiliki pengertian di mana para pendengar mendapatkan berkat dari Allah. Itu berarti bahwa setiap orang dituntut untuk mampu menguasai lidahnya agar setiap perkataan yang diucapkan dapat membangun orang lain.

Dengan menjaga kesucian perkataan dan tingkah laku secara otomatis hal ini akan memberikan kesucian dalam hati dan pikiran. Karena ucapan dan perilaku merupakan cerminan hati dan pikiran. Hanya dengan kebersihan dan kesucian hati dan pikiran maka Timotius dapat menjadi teladan, bukan hanya bagi orang percaya saja, tetapi juga bagi semua orang yang mengenalnya. Timotius harus mewujudkan dalam kehidupannya apa yang diajarkannya dalam khotbahnya.

\section{Menjadi Teladan dalam Tingkah Laku}

Dalam Bahasa Yunani avnastrofh (anastrophe) artinya cara hidup

(In conduct) artinya dalam perilaku. Kata ini ditulis dalam bentuk kata benda yang feminim tunggal. Dalam Exegetical Dictionary of New Testament memberikan arti bahwa istilah ini adalah merupakan kata neutral/netral secara etik menunjukkan bahwa konteks ini menentukan apakah ini memiliki pengertian positif atau negatif. ${ }^{7}$ Ini mengembangkan nilai etika sebagai sesuatu yang berkaitan dengan sikap dan perilaku yang telah didefinisikan dengan tegas. Dalam Ibrani 13:7, kata ini digunakan sebagai perbuatan atau tingkah laku dari pemimpin rohani dari orang Kristen. Ini digunakan sebagai perilaku atau tingkah laku orang Kristen dalam Yakobus 3:13. Petrus menggunakan kata "perilaku" orang Kristen yang dia inginkan sebagai cara yang ilahi. Petrus menggunakan kata perilaku dari istri orang Kristen (1 Petrus 3:1-2). Dia juga menggunakan kata "tingkah laku" yang tidak ilahi dari Sodom dan Gomora (2 Ptr 2:7).

Frederick W. Danker "conduct expressed according to certain principles way of life, conduct", dalam bahasa Indonesia menyatakan bahwa "tingkah laku yang diungkapkan sesuai dengan prinsip-prinsip tertentu dalam cara hidup kata ini merujuk pada perilaku atau gaya hidup yang diekspresikan menurut prinsip-prinsip tertentu. Sehingga ini mengacu kepada fakta bahwa Paulus menginginkan gaya hidup Timotius yang ilahi, yang menggambarkan standar kesucian atau standar keilahian dari Injil. ${ }^{8}$ Paulus menginginkan perilaku Timotius sesuai dengan jabatannya di dalam Kristus

\footnotetext{
${ }^{7}$ William Mounce, The Analytical Lexicon To The New Testament (Michigan: Zondervan Publishing House, 1993). Hal. 11

${ }^{8}$ Frederick W. Danker, Hope as the Basis for Holiness (Dallas Chicago: C\&L Publicitions Inc, 2000).
} 
dan menggambarkan standar kesucian dari Injil. Kata ini berhubungan dengan pelayanan orang banyak dimana mengacu kepada apa yang didapati oleh orang lain dalam kehidupan Timotius. Kata anastrophe ini merupakan objek dari kata depan en yang berfungsi sebagai penanda pengertian yang menunjukkan bahwa Timotius harus menjadi teladan bagi jemaat Kristen di Efesus melalui perilaku dan secara khusus melalui tingkah laku. "Melalui perbuatan" menunjukkan bahwa Timotius adalah teladan bagi orang Kristen Efesus melalui perilaku dan secara khusus perilaku yang ilahi. Ini mengacu kepada perilaku, atau gaya hidup yang diinginkan oleh Paulus untuk dilakukan dengan mengacu kepada mereka yang lebih tua atau dewasa dalam jemaat Efesus.

\section{Menjadi Teladan dalam Kasih}

Dalam bahasa Yunani "avgaph" (Agape)artinya kasih dalam bahasa Inggrisnya loved, goodwill, beloved, love, love's, love feasts. Artinya dicintai, niat baik, Keteladanan Hidup Dalam Tingkah laku dalam kasih yang bahasa Yunaninya, " $\varepsilon v \alpha \gamma \alpha \pi \eta "$ artinya dalam kasih. Elfrida Siringo-ringo menyatakan:

Kasih adalah hal yang fundamental dalam agama yang benar, keharmonisan mengikat para anggota jemaat. Wahyu ketuhanan sebagai Allah yang kasih adalah khas dari agama Yahudi-Kristen. Lebih dari anggota agama lain, Kristen sadar menikmati kasih yang saling menguntungkan antara mereka dan Allah. Kasih adalah kebutuhan yang dominan diperlukan kebajikan dalam agama Yahudi-Kristen.Kasih adalah hubungan manusia dan dalam hubungan antar manusia adalah di hati kehidupan Kristen dan ajaran. Kasih juga merupakan pra-syarat untuk menjadi warga yang baik, tetangga yang baik, atau suami atau istri yang baik atau orangtua. ${ }^{9}$

Dalam 1 Timotius 4:12 terdapat kata benda kasih yang diterjemahkan dari kata yang bahasa Yunaninya avgaph (agapēi) datif maskulin orang pertama tunggal berasal dari kata avgaph (agapē). Beberapa penggunaan kata avgaph (agapē): kasih atau kehendak baik. Kasih ini dinyatakan pada sesama manusia dan kepada Tuhan. Kadang-kadang juga pemakaiannya untuk kasih Tuhan kepada manusia (Roma 5:8). Kasih adalah sifat Ilahi yang terutama dalam kehidupan Kristen.Kasih lebih besar dari iman dan pengharapan, lebih mulia dari segala karunia Roh Kudus yang ajaib, sebab kasih tidak berkesudahan. Semua akan lenyap, tetapi kasih tetap

\footnotetext{
${ }^{9}$ Elfrida Siringo-ringo, "Penerapan Keteladanan 1 Timotius 4:14 Bagi Keluarga
} Gereja Maranatha Medan” (STT Anugrah Medan, 2018). Hal. 8 
kekal selama-lamanya (1 Kor.13:8,13). Tidak ada ciri seorang Kristen yang lebih menonjol dari pada kasih.

Dengan demikian semua orang akan tahu, bahwa kamu adalah murid-murid-Ku, yaitu jika kamu saling mengasihi (Yoh. 13:35). Pasal yang paling agung mengenai kasih di dalam Alkitab adalah 1 Korintus 13. Karena jikalau kasih tidak menjadi ciri kehidupan seseorang, maka kosonglah kehidupannya. Petrus berkata, "Tetapi yang terutama: kasihilah sungguhsungguh seorang akan yang lain, sebab kasih menutupi banyak sekali dosa" (1 Pet. 4:8). Dalam Bahasa Yunani terdapat tiga macam kasih yakni: Pertama, E $\rho \omega \varsigma$ dibaca Éros bahasa inggrisnya eros yaitu kasih birahi atau hawa nafsu manusia. Kedua, $\alpha \rho \chi \varepsilon i ́ o$.

Dibaca archeío dalam bahasa inggrisnya fileo yaitu kasih manusia secara alamiah, misalnya suami terhadap istri, Bapak terhadap anak, Ibu terhadap anak, anak terhadap orangtua dan sebagainya. Ketiga, agape yang bahasa Yunaninya "avgaph" (Agape) yaitu kasih yang dinyatakan oleh Yesus Kristus

Sementara Bahasa Yunani Sehari-Hari pada abad pertama menggunakan empat macam kasih yakni: Pertama, storge yaitu kasih sayang yang terjalin di antara persahabatan. Kedua, philos yaitu kasih yang terjalin dalam anggota keluarga. Ketiga, eros yaitu kasih yang bersifat romantis. Ketiga macam kasih ini merupakan pemberian Allah bagi manusia supaya manusia saling mengungkapkan kasihnya. Sedang yang keempat adalah agape yaitu kasih ilahi, kasih yang unik; kasih Allah kepada manusia lebih rinci menjelaskan arti keempat istilah kasih tersebut. Pertama, agape yaitu kasih yang paling tinggi dan mulia, yang mana tidak melihat nilai dari objeknya. ${ }^{10}$

Ini digunakan untuk menjelaskan tindakan pengorbanan tanpa ada maksud yang jahat, baik bagi diri sendiri maupun bagi orang lain. Juga digunakan untuk menggambarkan kasih Allah kepada manusia, kasih manusia kepada Allah, dan kasih manusia kepada sesamanya dalam bentuk yang umum. Kedua, eros yaitu kasih yang dinyatakan kepada lawan jenis, pria dan wanita. Ketiga storge, yaitu kasih yang menunjukkan kehangatan yang diberikan kepada orang-orang yang dekat, seperti kawan. Keempat, philia yaitu kasih sayang yang lebih umum digunakan dalam hubugan keluarga, orang tua dengan anak-anaknya.

Dalam The New Bible Dictionary kata kasih agape didefinisikan dalam bahasa Yunani sebagai bentuk kasih yang tertinggi dan termulia, yang

${ }^{10}$ Robert, Hidup Suci: Panggilan Bagi Setiap Orang Kristen (Bandung: Lembaga Literatur Baptis, 1988). Hal. 13 
melihat obyeknya sebagai sesuatu yang sangat berharga. ${ }^{11}$ Allah menghendaki agar manusia saling mengasihi satu dengan yang lain, dengan kasih agape, sebab ketiga kasih, yakni storge, philo dan eros hanya dapat berfungsi dan terjalin dengan baik sebagaimana mestinya jika didasari oleh kasih agape. Jadi, dengan adanya kasih agape, maka dalam suatu kehidupan yang suci, yaitu kehidupan yang dipimpin oleh Roh Kudus, ketiga macam kasih ini dapat berfungsi pada tempatnya dan terjalin dengan baik.

Ada perbedaan antara kasih yang merupakan kebutuhan dengan kasih yang merupakan pemberian/karunia (gift-love). ${ }^{12}$ Mengenai kasih yang merupakan kebutuhan. Di sini jelas bahwa kasih yang dipraktikkan Yesus adalah kasih yang melampaui kasih manusia yaitu kasih bukan karena, tetapi kasih walaupun. Umumnya manusia mengasihi sesamanya karena ada sesuatu yang diharapkannya dari orang tersebut. Selain itu, orang mengasihi sesamanya selalu mempertimbangkan banyak faktor, seperti; melihat status sosial, ekonomi, hubungan persaudaraan, dan karena sebab akibat. Artinya, seseorang mengasihi karena orang lain mengasihinya. Manusia mengasihi sesamanya karena sebelumnya telah menerima suatu perlakuan yang baik atau menguntungkannya, atau karena ada sesuatu yang diharapkan. Kasih Allah sama sekali berbeda, oleh karena kasih Allah adalah pemberian tanpa kepentingan dan tidak mementingkan diri sendiri, melainkan memberikan diri sendiri.

Arti sebenarnya dari kata agape adalah kebajikan yang tak dapat dihalangi. Jika orang Kristen memperlakukan seseorang dengan agape, maka segala tingkah laku dan perbuatan orang tersebut tidak akan menghalangi orang Kristen untuk tetap melakukan yang terbaik baginya sekalipun orang tersebut menghina atau menyakiti hati, orang Kristen tetap bersikap baik dan mengusahakan yang terbaik baginya. Dapat dipahami bahwa kasih kristiani bukanlah sesuatu yang bersifat emosional, yang hanya keluar dari perasaan, tetapi juga keluar dari kemauan. Agape adalah kasih ilahi, kasih yang unik. Kasih itulah yang dinyatakan dan dibicarakan di dalam Alkitab.

Berdasarkan uraian di atas dapat disimpulkan bahwa teladan dalam kasih harus tampak dalam kasih agape, yaitu kasih yang sejati, kasih ilahi, kasih tanpa syarat, kasih yang rela berkorban, kasih yang tidak akan digoyahkan oleh karena situasi dan kondisi yang bangaimana pun buruknya. Ini menunjukkan bahwa kepribadian seorang pendidik dan pengajar yang berketeladanan harus memiliki agape. Dalam agape, seorang pendidik dan

${ }^{11}$ Graham, Roh Kudus: Kuasa Allah Dalam Hidup Anda (Bandung: Lembaga Literatur Baptis, 1978). Hal. 24

${ }^{12}$ Robert, Hidup Suci: Panggilan Bagi Setiap Orang Kristen. Hal. 33 
pengajar tidak hanya mampu mendoakan musuh-musuhnya, tetapi juga mampu memberkati orang yang membencinya.

\section{Menjadi Teladan dalam Kesetiaan}

Dalam Bahasa Yunani pistij(pistis) artinya kepercayaan, iman, kesetiaan, agama, ajaran, yang diimani, janjinya, buktinya. dalam bahasa Inggrisnya: trustworthy artinya dapat dipercaya, faithful artinya setia, dependable artinya dapat diandalkan, inspiring trust or faith artinya kepercayaan atau iman yang menginspirasi, cherishing faith or trust artinya menghargai iman atau kepercayaan, also believing artinya juga percaya, trusting artinya penuh kepercayaan, faithful of christian believers artinya setia orang percaya Kristen.

Kata ini ditulis dalam bentuk kata sifat normal maskulin genitive jamak tidak ada derajat. Istilah bahasa Yunani pistis secara khusus merespon istilah bahasa Ibrani נאמן cara baca emunah, "kesetiaan", "kepercayaan". Dalam bahasa inggrisnya trustee, guardian artinya wali, regent artinya bupati, proxy artinya orang yang diberi kuas/mandat, custodian artinya pemelihara, executor artinya pelaksana.

Kata benda emunah ini terdapat 48 kali dalam Alkitab bahasa Ibrani yang adalah salah satu yang memiliki pengertian 'keteguhan' atau 'ketabahan'. Perbedan ini tentu dapat ditarik antara kata benda dan kata kerja yang berhubungan setidaknya dalam konteks di mana kata benda mengacu kepada kualitas perbuatan manusia. Kata benda emunah ini mengacu kepada tindakan dalam pengertian kesadaran. Contoh yang jelas adalah dalam 2 Raja-raja 12:15, di mana ini dicatat bahwa pekerjaan manusia memperbaiki bait suci adalah dilakukan dengan penuh kesadaran.

Yosafat bertindak sebagai hakim penanggung jawab untuk bekerja dengan kehati-hatian dan dengan hati yang jujur (2 Tawarikh 19:9). Ini memiliki kualitas yang sama yang mengarah pada Daud dan Samuel yang menunjuk orang tertentu sebagai penjaga pintu, mereka yang memiliki jabatan terhadap kehati-hatian mereka (1 Tawarikh 9:22). Teks ini akan terbaca "sebuah kepercayaan". Kata benda emunah adalah digunakan untuk Tuhan dan mengungkapkan kesetiaan-Nya dan ketergantungannya (Ulangan 32:4). Emunah juga digunakan untuk merujuk pada mereka yang memiliki kehidupan yang ditetapkan oleh Tuhan di mana Dia mengharapkan untuk melihat kesetiaan di dalam diri mereka.

Dalam hal ini, kepercayaan atau kehidupan iman adalah ciri dari mereka yang dibenarkan di mata Allah (Habakuk 2:4).Firman Allah tentang kebenaran ini menetapkan jalan kebenaran atau keteguhan bagi manusia 
(Maz 119:30).Dari keadaan ini kita dapat melihat sebuah konsep tugas yang dipercayakan kepada orang percaya yang menjadi kepercayaannya (Tanggung jawab iman, 1 Tawarikh 9:22; 2 Tawarikh 31:15, dll) atau jabatannya. Emunah tidak merupakan kualitas yang abstrak, reliabilitas, tetapi cara bekerja yang menumbuhkan stabilitas dengan keteguhan. Ini menekankan sikap dari dalam seseorang dan melakukannya dan kemudian membawa gagasan tentang stabilitas dari dalam dan berintegritas.

Ini menjelaskan tindakan kepercayaan dalam Perjanjian Lama, dan juga dimensi eksistensi manusia dalam situasi historis. Seperti Logos, "ucapan' anastrophe, 'perilaku' dan agape 'kasih ilahi', pistis, 'kesetiaan' adalah dihubungkan dengan pelayanan publik dari Timotius. Seperti agape, 'kasih ilahi' ini secara eksplisit menekankan bahwa Timotius adalah setia dalam memenuhi tanggung jawabnya dengan merujuk kepada jemaat Kristus di Efesus sehingga akan memperoleh penghargaan. Ini menjelaskan bagaimana Timotius menjadi teladan ilahi bagi orang Kristen lain untuk menirukannya dalam pengertian ini mendefinisikan bahwa dia memiliki kesetiaan dalam memenuhi tanggung jawabnya sebagai gembala dan memelihara kawanan domba Allah di Efesus.

Oleh karena itu, seperti agape, pistis adalah merujuk pada pelayanan publik Timotius dan menotasikan kesetiaan yang harus diamati dalam hidupnya dikalangan jemaat Kristen di Efesus. Ini berfungsi sebagai objek kata depan en yang juga memberikan tanda pengertian bahwa Timotius adalah menjadi contoh bagi orang percaya 'dengan memiliki kesetiaan'. Oleh

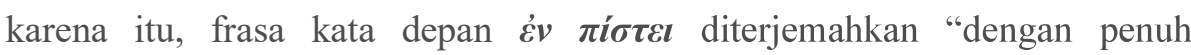
kesetiaan."

Jadi pengertian teladan dalam kesetiaan ialah bagaimana Timotius menjadi teladan keilahian bagi orang Kristen lain untuk ditiru dalam pengertian ini mendefinisikan bahwa dia setia dalam memenuhi tanggung jawabnya untuk menggembalakan dan memelihara kawanan domba Allah di Efesus. Oleh karena itu, seperti frase preposisional sebelumnya ini mengacu kepada pelayanan umum Timotius dan mengkonotasikan kesetiaan yang harus diamati dalam kehidupannya di antara orang Kristen di Efesus.

\section{Menjadi Teladan dalam Kesucian Hati}

Kata benda kesucian dalam 1 Timotius 4:12 diterjemahkan dari kata yang bahasa Yunaninya evnagneia (enhagneiai) cara baca: hagneia yang berarti dalam kemurnian atau kesucian. Ditulis dengan kata benda bentuk datif tunggal, dalam bahasa Inggisnya: purity artinya kemurnian, esp. chastity artinya kesucian. Semua terjemahan bahasa Inggris menggunakan 
kata purity yang berarti kemurnian sikap yang harus ditunjukkan oleh Timotius di dalam seluruh kehidupannya. Kata a gneial (hagneiai) ini lebih menunjuk kepada kesucian dalam hal moral sebagai salah satu dari lima nilai (virtue) yang disarankan oleh Paulus sebagaimana yang seharusnya dilakukan oleh seorang pengajar atau pemimpin jemaat. ${ }^{13}$

Barnes (Albert Barnes' Notes) mengomentari Roma 1:26-27, dan menulis bahwa yang dimaksudkan di sini adalah agar Timotius menjauhkan diri dari pikiran yang sesat dan lalim serta menjauhkan diri dari hawa nafsu dosa seks. ${ }^{14}$ Sependapat dengan pandangan Barnes di atas, Clarke (Adam Clarke's Commentary on Corinthians to Revelation) menyatakan bahwa kemurnian disini mengarah pada kemurnian tubuh dan pikiran. Peringatan ini dimaksudkan agar Timotius menjaga dirinya terhadap godaan wanita yang dapat menjadi godaan besar bagi seorang laki-laki muda. Jadi sebagai orang muda dalam pelayanan perlu dijaga, khususnya dalam hal dosa seksual dan cara memperingati seseorang. Jadi, sebagai seorang muda, Timotius diingatkan untuk menjaga kemurnian dalam hal percakapan, bahasa, kasih, iman, dan perbuatan. Posisi orang yang menerima Kristus adalah suci, karena Kristus telah menyucikan melalui pengorbanan-Nya di kayu salib. Kata suci berarti berorientasi pada Yang Suci. Dalam Kamus Besar Bahasa Indonesia Suci berarti bersih, bebas dari dosa, murni. Sedang 'kesucian' berarti kebersihan hati, kemurnian". ${ }^{15}$ Dalam bahasa Inggris ada tiga kata yang digunakan untuk kata suci yakni: Pertama, holy yaitu, suci. Kedua, whole yaitu sehat dan Ketiga, holistic yaitu utuh. Ketiga kata ini memiliki akar yang sama serta mempunyai makna yang saling berkaitan dan melengkapi.

Kesucian berarti pangkal kesehatan yang menjamin keutuhan sebuah organisme atau. Kesucian menyangkut kemurniaan hati dan hal memerintah diri sendiri. Jadi, kesucian adalah prasyarat utama untuk hidup sehat, baik secara jasmani terlebih secara rohani. Dapat dipahami bahwa hidup suci adalah hidup yang telah diperbaharui, dibenarkan, diselamatkan, dan dipisahkan dari kehidupan yang berdosa. Dalam hubungannya dengan kesucian, maka Paulus menasihati Timotius soal standar moral hamba Tuhan.Paulus tahu bahwa Timotius masih muda sehingga mudah terpengaruh oleh dosa. Firman Tuhan mengajar agar setiap orang mampu untuk menjadi teladan dalam kesucian. Kesucian berarti kesetiaan kepada standar Kristus, kesetiaan yang tak dapat ditaklukkan. Itu berarti, kesucian perlu ditunjukkan dengan pengendalian diri terhadap godaan dosa. Seorang

\footnotetext{
13 "Bible Work," n.d.

${ }^{14}$ Ibid.

15 "Suci," https://kbbi.web.id/suci.
} 
Kristen harus mempunyai standar kehormatan dan ketulusan hati, pengendalian diri dan kesucian, disiplin dan tanggung jawab yang lebih tinggi daripada standar dunia.

Kesucian hati sangatlah penting karena kita hidup di dalam dunia yang jahat sekarang ini. Efesus sebuah kota yang menjadi pusat penyimpangan seksual, dimana pada saat pelayanan Timotius sebagai orang muda diperhadapkan kepada banyak godaan. Ia harus mempunyai hubungan yang murni dengan perempuan-perempuan di dalam jemaatnya dan harus berhikmat bagaimana ia harus melayani berbagai perempuan seperti Firman Tuhan dalam 1 Tim 5:2 dikatakan jika ada terdapat perempuan sudah tua ia harus memanggilnya ibu dan jika perempuan yang masih muda ia memanggilnya sebagai adik. Ia harus memelihara agar pikiran, hati, dan tubuhnya tetap suci. Paulus menasihati Timotius agar memiliki iman yang teguh, kasih yang semakin besar dan terutama supaya ia menjadi teladan dalam kesucian hidup.

Pengendalian diri atau penguasaan diri/menahan diri adalah

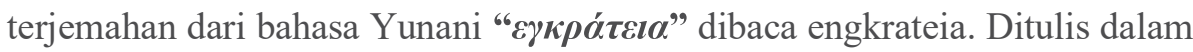
kata benda Dalam bahasa inggrisnya adalah abstinence artinya menahan diri, continence artinya penahanan nafsu, temperance artinya kesederhanaan.Senada dengan apa yang disampaikan oleh Graham mengatakan, penguasaan diri berasal dari kata Yunani engkrateia yang berarti kuat, telah menguasai, dapat mengontrol pikiran dan sikap pribadi. ${ }^{16}$ Kata engkrateia berasal dari kata bahasa Yunani kratos, "kekuatan" (Vine; bahasa Yunani yang diterjemahkan kuasa. Menurut Plato yang diedit oleh Tobias Hoffman; "some of the basic features of the classically conceived life of virtue. As I have been discussing, he redifines of temperance to mean selfrestrain and then blurs the distinction between self-restrain and weakness of will-moves that are likely to make him seem morbidly pre-occufied with in voluntary desires, especially of the sexual sort". Dalam bahasa indonesianya"Beberapa fitur dasar dari kebajikan dalam kehidupan yang dikonsep secara klasik. Seperti yang telah saya diskusikan, ia mengubah kesederhanaan menjadi pengekangan diri dan kemudian mengaburkan perbedaan antara pengekangan diri dan kelemahan kemauan bergerak yang kemungkinan besar akan membuatnya tampak tidak sehat dalam hasrat sukarela, terutama hal seksual. ${ }^{17}$

\footnotetext{
${ }^{16}$ Graham, Roh Kudus: Kuasa Allah Dalam Hidup Anda. Hal. 36

${ }^{17}$ Tobias Hoffman, Weakness Of Will From Plato To The Present (Press, Washington D.C, 2008). Hal. 64
} 
Pengendalian diri dalam terjemahan King James Version (KJV) berarti kesederhanaan dan penguasaan diri. Kata yang dipakai oleh dalam KJV adalah temparance yang berarti menguasai keinginan diri dan nafsu/hasrat diri. ${ }^{18}$ Sedang menurut Sidjabat pengendalian diri merupakan ketenangan dan pengendalian atas dorongan-dorongan yang timbul dalam hati dan pikiran agar dapat mencapai hidup yang lebih baik. Allah mengehendaki supaya manusia mengendalikan dirinya dalam hawa nafsu (Ams. 23:1-3), perkataan (Ams. 25:1-2), pengendalian lidah (Yak. 3:5-10). ${ }^{19}$ Paulus memberikan peringatan yang sama juga kepada para penatua di Efesus dalam pesan perpisahannya, 'Jagalah dirimu' (Kis. 20: 28). Itu berarti mengawasi diri merupakan sesuatu yang sangat urgen, mengingat sekarang ini banyak hamba Tuhan yang telah meninggalkan pelayanan karena kehidupan mereka tidak sesuai dengan pekerjaan sebagai hamba Tuhan.

Seorang pendidik dapat saja terlalu sibuk menolong orang lain sehingga ia melalaikan dirinya dan kehidupan rohaninya sendiri. Itu sebabnya sehingga seorang pendidik perlu mengawasi dirinya sendiri sebelum mengawasi orang lain. Dalam Alkitab ada nasihat agar setiap orang mengawasi diri sendiri terlebih dahulu, bukan orang lain. Dalam konteks itulah rasul Paulus mengingatkan, "Baiklah tiap-tiap orang menguji pekerjaannya sendiri; maka ia boleh bermegah melihat keadaannya sendiri dan bukan melihat keadaan orang lain" (Gal. 6:4). Penguasaan diri adalah kemampuan menguasai diri dengan pertolongan kuasa Roh Kudus. Artinya, Roh Kudus yang tinggal di dalam diri manusia akan memampukan manusia untuk mengendalikan diri.

Dalam konteks pendidikan, ada dua sisi yang merupakan syarat penentu keberhasilan seorang pendidik yakni:

a. Kepribadian: Kehidupan pribadi seorang pendidik sangat menentukan gerak-gerik pelayanan dan penanganan tugas-tugasnya. Seorang pendidik yang gagal secara pribadi dalam berumah tangga atau dalam kehidupan pribadi lainnya, maka hal itu sangat berpengaruh atas seluruh tugas dan pelayanannya. Dalam mengajar, kepribadian seorang pendidik jauh lebih disoroti dan diselidiki dibandingkan dengan orang-oranglain. Jatuh bangunnya seorang pendidik sangat bergantung kepada kehidupan pribadinya. Seorang pendidik haruslah berkepribadian terbuka dan tidak kaku, bersedia menerima pendapat orang lain dan mudah mengaku salah jika memang bersalah serta mengampuni sesama.

18 "Bible Work."

${ }^{19}$ Sidjabad B. S, Membesarkan Anak Dengan Kreatif (Yogyakarta: Andi Offset, 2008). Hal. 48 
b. Kerohanian: kerohanian merupakan prinsip utama dalam pendidikan. Kekuatan pendidik tidak diukur dari yang dapat dikerjakan, tetapi diukur dari hubungannya dengan Tuhan. Jadi seorang pendidik haruslah berpikir secara alkitabiah, karena pengajarannya bersumber pada apa yang dikatakan Alkitab; konsep pengajarannya adalah konsep Alkitabiah. Penekanan pada kata "dirimu sendiri" menegaskan bahwa pendidik sendiri perlu memiliki doktrin yang benar. Dalam mengajar, pendidik harus terus bertekun dalam melaksanakan tugas yang telah dipercayakan kepadanya.

Dalam kesimpulan Penulis dari dalam konteks pendidikan diatas bahwa dalam mengawasi diri sendiri terhadap hubungan dengan orang lain, pendidik harus memiliki tata krama, sikap hidup benar, tidak pemarah, dan memiliki kesalehan hidup. Dalam hubungan dengan agama, pendidik harus memiliki kesalehan sejati dan maju dalam pengetahuan dan kasih Allah, dan dalam hubungan dengan moral, pendidik juga harus tegas dalam berhubungan dengan orang lain dan kebiasaan pribadinya harus rapi, bersih, benar, konsisten, sopan, dan mampu menunjukkan sikap yang adil terhadap agama, sehingga tidak menyebabkan adanya pelanggaran. Jadi, seorang pendidik harus mampu menjadi teladan dalam perkataan. Perilakunya tidak boleh bertentangan dengan hukum dan sopan santun yang berlaku.

\section{Aplikasi Terhadap Pembentukan Kualitas Karakter Peserta Didik} Seorang Guru Harus Menjadi Teladan Dalam Perkataan

Guru PAK harus menjadi teladan/pola dalam kehidupannya, yaitu di tengah-tengah keluarga, lingkungan masyarakat, lingkungan sekolah. Keteladanan guru Pak itu boleh terlihat dari gaya hidupnya sehari-hari di waktu guru PAK melakukan aktifitasnya sehari-hari. Yaitu dengan cara menjaga hati (Amasl 4:23). Jagalah hatimu dengan segala kewaspadaan, karena dari situlah terpancar kehidupan". Untuk menjadi teladan harus mampu menjaga hatinya untuk menghadapi situasi-situasi peserta didiknya atau pun rekan-rekan kerjanya. Karena kerendahan hati itu menghasilkan kelemahlembutan dan tidak sombong sehingga orang akan melihat suatu contoh/teladan yang baik untuk ditiru.

Perkataan memegang peranan yang sangat penting dalam kehidupan setiap orang khususnya dalam pergaulan dengan orang lain. Dalam sebuah keluarga, perkataan yang digunakan sangat berpengaruh pada perkembangan anak. Perkataan yang baik dapat memberikan kesehatan rohani, mental dan jasmani Allah mengajarkan agar setiap orang tidak menggunakan ucapan yang negatif, khususnya orang tua kepada anak-anaknya karena perkataan 
yang negatif seperti goblok, bodoh, canggung, malas, pemalu, buruk, dan lain-lain dapat membuat anak menjadi sosok yang tidak percaya.

Segala ucapan negatif yang diterima anak akan melekat dalam hatinya, dan mereka akan cenderung menjadi sosok dan bertindak seperti julukan yang diberikan kepadanya. Daripada orang tua memberikan julukan negatif kepada anak-anaknya, akan lebih baik jika orang tua atau guru memberikan pujian kepada anak-anaknya. Memuji anak-anak merupakan tindakan dan sikap yang positif. Dengan memberikan pujian kepada anak, mereka akan bertumbuh menjadi anak yang dapat bersyukur kepada Tuhan dan menghargai orang lain. Dapat dipahami bahwa setiap orang, baik yang tua maupun yang mudah harus berusaha untuk dapat menguasai lidahnya sehingga setiap perkataan yang keluar dari mulutnya bukanlah perkataan yang sia-sia dan perkataan yang kotor, tetapi perkataan yang dapat membangun orang lain. Paulus mengatakan, dalam Efesus 4:29: "Janganlah ada perkataan kotor keluar dari mulutmu, tetapi pakailah perkataan yang baik untuk membangun, di mana perlu, supaya mereka yang mendengarnya beroleh kasih karunia".

Kata-kata kotor yang membinasakan dikatakan keluar dari mulut sebetulnya berasal dari hati. Daripada menggunakan kata-kata kotor yang keluar dari hati, disarankan untuk menggunakan kata-kata yang bersifat baik dengan istilah yang digunakan Paulus "logos agathos". Sebab perkataan yang baik akan mendatangkan kebaikan atau membangun bagi yang mendengarnya. Membangun bagi mereka yang mendengarnya memiliki pengertian di mana para pendengar mendapatkan berkat dari Allah. Itu berarti bahwa setiap orang dituntut untuk mampu menguasai lidahnya agar setiap perkataan yang diucapkan dapat membangun orang lain.

Dengan menjaga kesucian perkataan dan tingkah laku secara otomatis hal ini akan memberikan kesucian dalam hati dan pikiran. Karena ucapan dan perilaku merupakan cerminan hati dan pikiran. Hanyadengan kebersihan dan kesucian hati dan pikiran maka Timotius dapat menjadi teladan, bukan hanya bagi orang percaya saja, tetapi juga bagi semua orang yang mengenalnya. Timotius harus mewujudkan dalam kehidupannya apa yang diajarkannya dalam khotbahnya.

\section{Seorang Guru harus Menjadi Teladan Dalam Tingkah Laku}

Frasa tanpa syarat ini menotasikan bahwa Paulus menginginkan gaya hidup Timotius yang ilahi yang merefleksikan atau mencerminkan standar yang suci atau standar yang ilahi dari Injil. Paulus menginginkan perilaku Timotius sesuai dengan jabatannya di dalam Kristus dan merefleksikan 
bahwa dia mengakui dan mematuhi standar kesucian Injil. Dia harus menyatakan cara yang ilahi. Perkataan ini terkait dengan pelayanan publik dari Timotius yang merujuk pada apa yang dapat ditiru oleh orang lain dalam kehidupan Timotius.

Jadi teladan dalam tingkah laku ini berhubungan dengan sikap hidup, tingkah laku seseorang yang harus sesuai dengan status keberadaan diri sebagai orang yang sudah percaya atau cara hidup yang sudah mengenal Kristus. Oleh karena itu, teladan dalam tingkah laku menjelaskan adanya perbedaan yang nyata dari sikap hidup seseorang berkaitan dengan identitasnya di dalam peserta didik Allah sebelum ia percaya dan sesudah ia percaya kepada Tuhan.

Sebagai guru PAK, harus memiliki karakter yang baik. Karakter guru PAK adalah hal yang menghasilkan kepercayaan pembelajar (peserta didik). Jadi kualitas hidup guru menghasilkan motivasi peserta didik sehingga pembelajar dapat melakukan apa yang baik. Pada dasarnya, belajar berarti berubah dalam pikiran, berubah dalam perasaan, berubah dalam prilaku, jadi belajar berarti perubahan yang terjadi di pikiran, pearasaan dan kehendak. Paulus menunjukkan hal ini dalam Roma 8:29 "Sebab semua orang yang dipilih-Nya dari semula, mereka juga ditentukan-Nya dari semula untuk menjadi serupa dengan gambaran anak-Nya". Sebagai pengajar disebut juga komunikator terhebat karena mereka adalah orang yang memiliki hati yang besar (hati yang baik). Guru berkomunikasi sebagai pribadi yang utuh dan berkomunikasi dengan pendengar yang juga sebagai pribadi yang utuh. Contoh: Abraham dan Nuh.

\section{Seorang Guru Harus Menjadi Teladan Dalam Kasih}

Guru Pendidikan Agama Kristen memiliki tugas yang sangat kompleks dan terpadu. Sebagai wujud nyata peranan guru PAK tersebut harus melaksanakan tugasnya dengan baik dan bertanggungjawab dalam mencapai tujuan pembelajaran yang sempurna. Salah satu tujuan Pendidikan Agama Kristen adalah siswa memiliki karakter yang baik seperti Tuhan Yesus Kristus. Sebab peran guru Pendidikan Agama Kristen sangat berpengaruh terhadap pembentuk karakter peserta didik. Bahkan Alkitab memberikan keterangan bahwa Yesus memberikan wewenang kepada para rasul, para nabi, para pengajar, para gembala dan para penginjil untuk mengajar dan membentuk karakter jemaat (peserta didik) menjadi dewasa dan sempurna (Efesus 4:11-16).

Sebab itu, guru pendidikan agama kristen perlu: 1. Menjaga kekudusan hidupnya sebagai mitra Allah dalam membina, membimbing para 
muridnya menjadi murid yang berkarakter seperti Dia; 2. Menyadari bahwa dirinya adalah Hamba Tuhan, tugas mengajar merupakan panggilan Allah yang harus dikerjakan dengan sungguh-sungguh. Guru Pendidikan Agama Kristen harus mempersiapkan dirinya sebaik mungkin sebelum mengajar; 3. Guru Pendidikan Agama Kristen harus menjadi teladan bagi siswa serta bersahabat dengan siswa sebagai bagian dari pembentukan karakter siswa. Didalam keseharian fungsi guru sebagai pendidik/pengajar dilingkungan sekolah hendaknya menerapkan tidak pilih kasih, terhadap peserta didik dalam hal penugasan pekerjaan; rumah, sekolah, dapat menjaga/mengontrol sikap, amarah dan memiliki rasa empaty terhadap keberadaan peserta didik dengan tidak mengabaikan ketegasan dalam tugas-tugas yang harus peserta didik lakukan. Seorang guru PAK juga harus mudah mengampuni apabila mungkin sesama rekan guru ada yang kurang sopan atau bertindak tidak baik terhadapnya atau ada orang tua bahkan peserta didik yang bertindak kurang ajar terhadapnya (guru PAK) maka sebagai mitra Allah seperti yang telah disebutkan diatas haruslah mudah mengampuni mereka dan tidak menyimpan dalam hati serta menganggap dirinya sebagai Hamba Tuhan yang Tuhan tetapkan menjadi pendidik yang Tuhan Allah percayakan kepada guru PAK tersebut.

\section{Seorang Guru Harus Menjadi Teladan Dalam kesetiaan}

Kesetiaan seorang guru PAK harus benar-benar dapat menjadi teladan bagi peserta didik. Menjadi seroang pengajar adalah suatu panggilan dan tidak semua orang punya hati untuk mengabdikan diri dan waktunya untuk orang lain/peserta didik yang akan mendapatkan ilmu/pengetahuan dari seorang pengajar. Seorang guru PAK harus benar-benar berkomitmen dengan panggilannya, dimana dalam implementasinya akan berhadapan dengan peraturan-peraturan dan standar yang berlaku dalam sebuah wadah/tempat guru tersebut ditempatkan. Ketika seorang guru bisa mentaati semua peraturan yang berlaku dan bisa menerima dan menjalankan semua standar yang berlaku ditempat dimana guru PAK tersebut mengajar atau mendidik, maka dikatakan guru tersebut setia dalam panggilannya.

Kesetiaan yang dimaksud menurut penulis tidak hanya sekedar mematuhi semua aturan dan peraturan yang hanya ada ditempat kerja namun juga ketika aturan tersebut sudah meluas hingga menjadi pekerjaan dirumah contoh: Kepala Sekolah menghimbau supaya guru PAK juga ikut terlibat dalam mempromosikan sekolah dimana guru PAK mengajar dilingkungan tempat tinggal guru PAK tersebut atau ditempat lain agar supaya masyarakat membawa anak-anak mereka untuk didik disekolah tempat guru PAK 
tersebut mengajar, maka guru PAK tersebutpun juga harus mengindahkannya artinya mau melakukannya bukan untuk membuat supaya kepala sekolah tersebut diatas senang, namun lebih-lebih menyangkut kepada kesetiaan diri guru PAK tersebut. Juga ketika seorang guru PAK berada dilingkungan rumah/ditengah-tengah masyarakat harus menunjukkan, mempertahankan kepribadiannya sebagai Hamba/Mitra Allah; jikalau contoh ada himbauan dari RT/RW setempat menghimbau masyarakat secara bergilir dalam bergotong royong dalam kamtibmas dan hal kebersihan, menyadari perlu keterlibatannya dalam program pemimpin lingkungan tersebut. Menjadi guru PAK adalah merupakan keteladan yang tidak terbatas alias harus komprehensif/menyeluruh dalam kehidupan.

\section{Seorang Guru Harus Menjadi Teladan Dalam Kesucian Hati}

Seorang Guru PAK harus dapat menahan diri terhadap segala hal khususnya hal moral dalam perkataan dan sikap/tindakan.Menjadi model/figur dalam setiap kesempatan baik apabila berada dilingkungan tinggal, lingkungan sosial maupun lingkungan kerja atau disekolah, dimana sebagai guru PAK. Seorang pendidik dapat saja terlalu sibuk menolong orang lainsehingga ia melalaikan dirinya dan kehidupan rohaninya sendiri. Itu sebabnya sehingga seorang pendidik perlu mengawasi dirinya sendiri sebelum mengawasi orang lain. Dalam Alkitab ada nasihat agar setiap orang mengawasi diri sendiri terlebih dahulu, bukan orang lain. Dalam konteks itulah rasul Paulus mengingatkan, "Baiklah tiap-tiap orang menguji pekerjaannya sendiri; maka ia boleh bermegah melihat keadaannya sendiri dan bukan melihat keadaan orang lain" (Gal. 6:4). Surat Paulus kepada Titus menekankan agar pemimpin gereja harus tidak bercacat cela dan tetap setia kepada firman Tuhan (Titus 1:6-9). Dalam surat itu, juga mengingat kan bahwa banyak orang kreta mengaku sebagai guru tetapi sebenar nya mereka adalah penyesat-penyesat yang mengaku mengenal Allah, tetapi dengan perbuatan mereka, mereka menyangkal. Mereka berkata bahwa mereka mengenal Allah, padahal perbuatan mereka menyangkal-Nya. Mereka menjijikkan dan mereka tidak mau taat; mereka adalah orang-orang yang tidak mampu melakukan sesuatu yang baik." (Titus 1:16). Seorang guru PAK haruslah mengajarkan peserta didik perilaku yang benar, kejujuran, rasa hormat, integritas, kebaikan dalam perkataan dan tindakan.

Seorang Pendidik/Guru PAK juga haruslah menjadi teladan dalam perkataan ketika mereka berada dilingkungan sekolah, contoh hal kesopanan dalam berpakaian. Seorang pendidik perlu mengajarkan dan mengingatkan peserta didik dalam penampilan agar terlihat indah dan rapi. Ketika 
pendidik/guru PAK tersebut melihat ada seorang peserta didik dikelas 6(enam) yang tidak berpakaian sopan, lalu menegornya. Artinya bukan berarti si guru PAK tersebut mengajarkan peserta didik untuk lain kali berpakaian menutupi seluruh tubuhnya atau pakaianya mulai dari kepala sampai ketumit, namun maksud dan tujuannya dikemudian hari adalah supaya peserta didik tahu meniru hal yang baik dan sopan dan pantas untuk ditampilkan didalam kelas. Namun juga supaya terjadinya sinkronisasi antara perkataan dan tindakan hendaklah juga si guru PAK yang menegor peserta didik tersebut harus menjadi teladan dalam perkataan dan sikap/tindakannya didalam kelas, sehingga dengan sendirinya sang peserta didik sadar akan keteladanan yang dilihat dan didapatkannya dari sang guru PAK tersebut.

\section{KESIMPULAN}

Untuk membentuk kualitas karakter peserta didik, Guru PAK harus meningkatkan kualitas kompetensi kepribadian sendiri. Adapun yang harus dilakukan untuk meningkatkan kompetensi dengan cara: Mengikuti Seminar Kerohanian didalam Kekristenan, Mengikuti Seminar Pedagogik, Mengikuti Seminar Kepribadian, Mengikuti Seminar Sosial dan Kebudayaan. Dan mengikuti Seminar Kompetensi Kepribadian Profesional lainya. Harus menjadi teladan dalam perkataan, tingkah laku, dalam kasih, dalam kesetiaan dan dalam kesucian hati.

Dalam mendidik, Guru harus sadar bahwa Peserta Didik adalah titipan Tuhan untuk didik dalam hal ini Guru PAK harus memainkan peranannya. Guru sebagai Pendidik harus memiliki standard kualitas Integritas, yang mencakup tanggung jawab, wibawa, kemandirian dan kedisiplinan dengan tugas mendidik Guru PAK, mengembangkan watak, nilai moral dan mampu mengembangkan Kompetensi Kepribadiannya untuk meningkatkan kualitas Karakter Peserta Didik menuju kedewasaan rohani yang beriman, taat kepada Tuhan Yesus Kristus.

Guru sebagai pemberi inspirasi, Guru harus mampu memerankan diri dan memberikan inspirasi bagi Peserta Didik sehingga kegiatan belajar dan pembelajaran dapat membangkitkan berbagai pemikiran, gagasan, dan ide-ide baru Peserta Didik. Guru sebagai Inisiator, harus dapat menjadi pencetus ide-ide kemajuan dalam pendidikan dan pengajaran. Guru sebagai Korektor, harus dapat membedakan nilai yang baik dan nilai yang buruk, semua nilai yang baik harus dipertahankan dan nilai yang buruk harus disingkirkan dari Peserta Didik. 


\section{KEPUSTAKAAN}

Ahmadi Rulam. Metodologi Penelitian Kualitatif. Yogyakarta: Arruzz media, 2014.

Andreas B.Subagy. Metode Penelitian Public Relations Dan Komunikasi. Yogyakarta, 2015.

Arnold E. airhart. Beacon Bible Commentary,. Vol. IX. Beacon Hill Press, 1969.

Danuwinta, SJ. Karya Lengkap Dryarkara, Fenomena Pendidikan. Jakarta: Gramedia Pustaka Utama, 2006.

David Susilo Pranoto. "Manna Reflesia." Sekolah Tinggi Teologi Arastamar Bengkulu, 2017.

Eka Budianta. Mekar Di Bumi. Jakarta: Pustaka Alvabet, 2006.

Elfrida Siringo-ringo. "Penerapan Keteladanan 1 Timotius 4:14 Bagi Keluarga Gereja Maranatha Medan." STT Anugrah Medan, 2018.

Frederick W. Danker. Hope as the Basis for Holiness. Dallas Chicago: C\&L Publicitions Inc, 2000.

Graham. Roh Kudus: Kuasa Allah Dalam Hidup Anda. Bandung: Lembaga Literatur Baptis, 1978.

H. Von Soden. Encyclopaedia Biblical. New Testament Chronology, 1899.

John Arthur Thomas Robinson. Redating The New Testament. Westminster Press, 1976.

Lexy J.Meleong. Metodologi Penelitiian Kualitatif. Bandung: Remaja Rosdakarya, 2002.

Linda Clarke. Teacher Status and Professional Learning, The Place Model. Ltd, Northwich: Critical Publishing, 2016.

Mounce, William. The Analytical Lexicon To The New Testament. Michigan: Zondervan Publishing House, 1993.

Noh Ibrahim Boiliu, Aeron Frior Sihombing, Christina M. Samosir, and Fredy Simanjuntak. "Mengajarkan Pendidikan Karakter Melalui Matius 5:6-12." Kurios (Jurnal Teologi \& Pendidikan Agama Kristen) 6, no. 1 (2020): 61-72.

Plato, Mamutty Chola. "Pearls of Wisdom,." BecomeShakespeare.Com, 2019.

Robert. Hidup Suci: Panggilan Bagi Setiap Orang Kristen. Bandung: Lembaga Literatur Baptis, 1988.

Robert Rubianto. "Pendidikan Budi Pekerti Mengikis Korupsi." BAHANA 217 (2017): 8.

Ruslan, Rosady. Metode Penelitian Public Relations Dan Komunikasi. Jakarta: Rajawali Pers, 2003.

Sidjabad B. S. Membesarkan Anak Dengan Kreatif. Yogyakarta: Andi Offset, 2008.

Talizaro Tafona'O. "Kepribadian Guru Kristen Dalam Perspektif 1 Timotius 4:11-16." Evangelikal 3, no. 1 (2019): 66.

Tatag Utomo. Mencegah Dan Mengatasi Krisis Anak Melalui Pengembangan Sikap Mental Orang Tua. Jakarta: Grasindo, 2003.

Tatang Muhtar, Teddy Supryadi \&Anggi Setia Lengkana. Pendidikan 
Karakter Dalam Pembelajaran Penjas. Bandung: CV. Salam Insan Mulia, 2019.

Tobias Hoffman. Weakness Of Will From Plato To The Present. Press, Washington D.C, 2008.

W.J.S Poerwadarminta. Metode Kuantitatif \& Kualitatif. Bandung, 2015. Wall Hollindale, Bakhtin, Stephens. Childrend's Literature Pat Pinsent.

Palgrave Mac Millan, United State: Copyright Licency Agency, 2016. "Bible Work," n.d.

"Suci."

"UU 20 Tahun 2003 Tentang Sistem Pendidikan Nasional." 